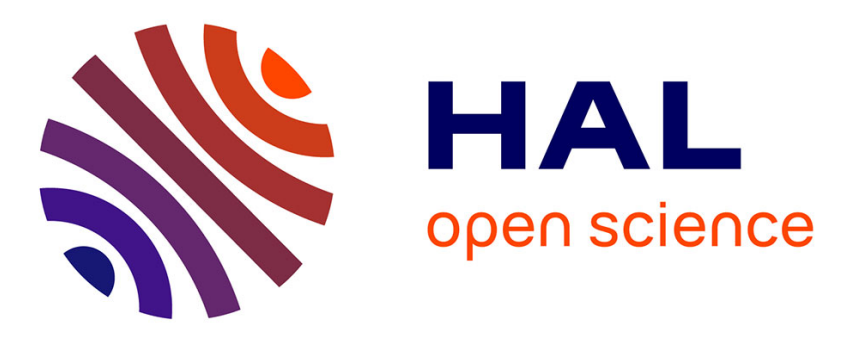

\title{
Chiral Phosphathiahelicenes: Improved Synthetic Approach and Uses in Enantioselective Gold(I)-Catalyzed [2+2] Cycloadditions of N-Homoallenyl Tryptamines
}

\author{
Valentin Magné, Youssouf Sanogo, Charles S Demmer, Pascal Retailleau, \\ Angela Marinetti, Xavier Guinchard, Arnaud Voituriez
}

\section{To cite this version:}

Valentin Magné, Youssouf Sanogo, Charles S Demmer, Pascal Retailleau, Angela Marinetti, et al.. Chiral Phosphathiahelicenes: Improved Synthetic Approach and Uses in Enantioselective Gold(I)Catalyzed [2+2] Cycloadditions of N-Homoallenyl Tryptamines. ACS Catalysis, 2020, 10.1021/acscatal.0c01819 . hal-03021769

\section{HAL Id: hal-03021769 \\ https://hal.science/hal-03021769}

Submitted on 24 Nov 2020

HAL is a multi-disciplinary open access archive for the deposit and dissemination of scientific research documents, whether they are published or not. The documents may come from teaching and research institutions in France or abroad, or from public or private research centers.
L'archive ouverte pluridisciplinaire HAL, est destinée au dépôt et à la diffusion de documents scientifiques de niveau recherche, publiés ou non, émanant des établissements d'enseignement et de recherche français ou étrangers, des laboratoires publics ou privés. 


\title{
Chiral Phosphathiahelicenes: Improved Synthetic Approach and Uses in Enantioselective Gold(I)-Catalyzed [2+2] Cy- cloadditions of $\mathbf{N}$-Homoallenyl Tryptamines
}

\author{
Valentin Magné, Youssouf Sanogo, Charles S. Demmer, Pascal Retailleau, Angela Marinetti, Xavier \\ Guinchard* and Arnaud Voituriez* \\ Université Paris-Saclay, CNRS, Institut de Chimie des Substances Naturelles, UPR 2301, 91198 Gif-sur-Yvette, France. \\ KEYWORDS. Phosphorus ligands; helicenes; gold catalysis; spirofused compounds; tryptamines; indolinecyclobutanes.
}

\begin{abstract}
A chiral phosphathiahelicene scaffold displaying a phosphole and a thiophene unit as the terminal rings of the helical sequence has been synthesized and characterized by spectroscopic methods and X-ray diffraction studies. The phosphine oxides (HelPhos-V oxides) have been obtained following a robust and scalable synthetic approach, based on a nickel-promoted alkynes cyclotrimerization reaction. Then, late-stage functionalization has been carried out via a bromination/palladium coupling reaction sequence. The HelPhos-V gold(I) complexes have been used as catalysts in the unprecedented enantioselective [2+2] cyclization of $\mathrm{N}$-homoallenyl tryptamine derivatives, to afford indolenine-fused cyclobutanes in good isolated yields, with enantiomeric excesses up to $93 \%$.
\end{abstract}

Helicenes and heterohelicenes represent a fascinating class of compounds that find applications in many different fields, including materials, optoelectronics, supramolecular assemblies, biology and asymmetric catalysis. ${ }^{1}$ However, the intrinsic chirality of helical scaffolds has been seldom harnessed for building phosphorus-containing helicenes for catalytic purposes. $^{2}$ This is especially true for phosphahelicenes, i.e. compounds where phosphorus heterocycles are embedded in the helical scaffold itself. In 2010 and 2012, Tanaka and Nozaki independently reported phosphahelicenes, wherein a phosphole ring was embedded in the internal section of the helical scaffolds (Figure 1a). ${ }^{3}$ Since 2012, ${ }^{4 a}$ our group has developed new families of phosphahelicenes, called "HelPhos-K, -Y, -S and -P" (Figure 1b), where a five-membered phosphorus ring is embedded at the end of helical structures. This allowed us to access unprecedented chiral tools for organo- and organometallic catalysis. As representative applications, HelPhos-K, HelPhos-S and HelPhos-P were used notably as ligands in gold(I)-catalyzed allene-ene cyclizations and enyne cycloisomerization processes $^{4 \mathrm{~b}-\mathrm{d}}$ and HelPhos-Y as chiral organocatalyst in [3+2] cyclizations between 2-arylidenemalononitriles and $\gamma$-substituted allenoates. ${ }^{4 \mathrm{e}}$ In most cases, very high levels of catalytic activity and enantioselectivity were reached. Thus, these previous achievements undoubtedly demonstrate the huge potential of HelPhos as chiral ligands and nucleophilic catalysts.

Concerning the strategies for the synthesis of helicene backbones, the most popular has been the oxidative photocyclization of diaryl olefins, developed more than fifty years ago. ${ }^{5}$ More recent approaches rely notably on Diels-Alder reactions, metal-catalyzed arylations, cycloisomerizations and alkyne cyclotrimerizations. ${ }^{1,6}$ For the synthesis of phosphahelicenes, we followed two main strategies: the photochemical oxidative cyclization of diaryl olefins ${ }^{4 a-c}$ and the nickel-catalyzed intramolecular $[2+2+2]$ cyclotrimerization of triynes. ${ }^{4 \mathrm{~d}}$

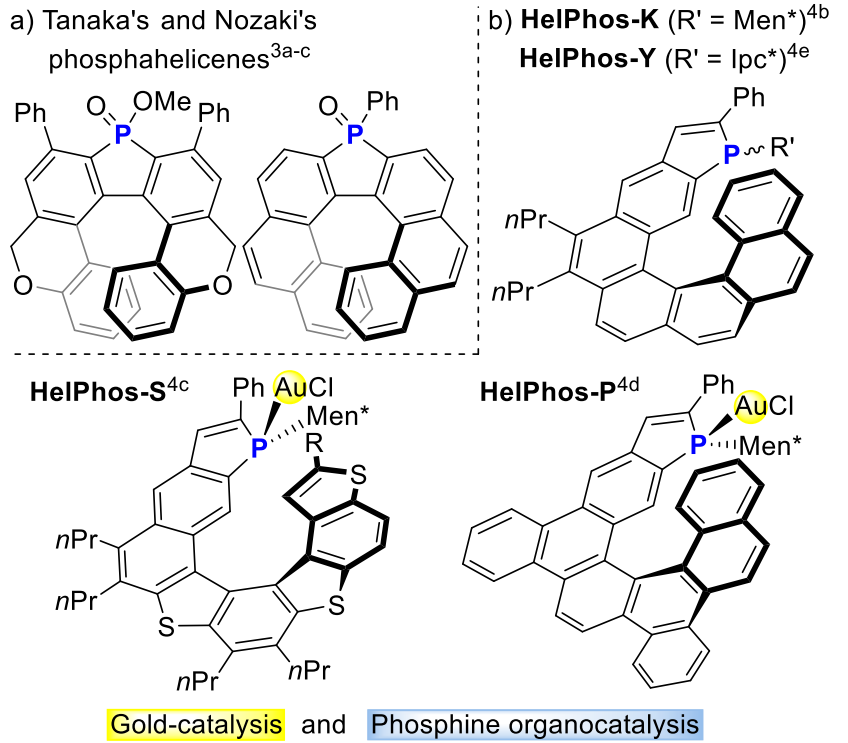

Figure 1. Tanaka's and Nozaki's phosphahelicenes and the HelPhos family $\left(\mathrm{Ipc}^{*}=\right.$ isopinocampheyl; Men* $=L$-menthyl).

So far, the most convenient synthetic approach is the one involving the nickel-catalyzed cyclotrimerization as the key step, that has been applied notably to the synthesis of HelPhos-P. ${ }^{4 d}$ Compared to the photocyclization-based approach, its main advantage is to be high yielding and easily scalable to gram amounts. On the other hand, we have demonstrated, in the HelPhos-S series, that terminal thiophene rings offer a valuable opportunity for late-stage functionalization and easy tuning of the substitution patterns of pre-formed helical scaffolds. We demonstrated also that the additional substituent on the terminal thiophene ring may have a positive 
impact on the enantioselectivities in catalytic tests. ${ }^{7}$ Therefore, in order to take advantage of both the cyclotrimerizationmethod and the late functionalization strategy, we have designed a new phosphahelicene scaffold, HelPhos-V, that should be accessible via a cyclotrimerization process and displays a terminal thiophene unit suitable for late-stage functionalization (Figure 2).

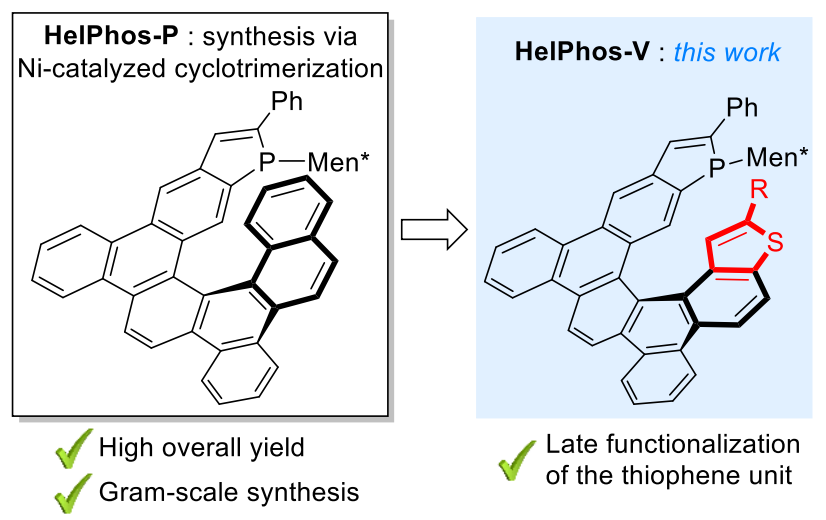

Figure 2. Design of the new phosphathiahelicene HelPhos-V.

In this paper, we will report on the synthesis of HelPhos-V using the cyclotrimerization strategy and the tuning of its substitution pattern. Complexation of the phosphine with $\mathrm{Au}(\mathrm{I})$ is reported, as well as the remarkable catalytic activity of the resulting chiral complexes in a new enantioselective gold-catalyzed [2+2] cyclization reaction, leading to spiranic indolocyclobutanes.

For the synthesis of the HelPhos-V ligand featuring the cyclotrimerization strategy, we first targeted triyne $\mathbf{6}$ as key intermediate (Scheme 1). This compound could be easily obtained in few steps and in gram-scale via a sequence of palladiumcatalyzed reactions. First, the methoxymethyl-protected 4ethynylbenzo[b]thiophen-5-ol $\mathbf{1}$ has been prepared in four steps from 5-hydroxybenzothiophene, by regioselective bromination in C4-position, protection of the alcohol with a MOM group, trans-halogenation $(\mathrm{Br} \rightarrow \mathrm{I})$ and Sonogashira coupling (see Supporting Information for details). Then, the Sonogashira coupling between $\mathbf{1}$ and the enantiopure phosphindole $(R)-2^{4 \mathrm{~d}}$ furnished the desired alkyne $\mathbf{3}$ in $91 \%$ yield (5.2 grams). The optimal reaction conditions involved $\mathrm{Pd}\left(\mathrm{PPh}_{3}\right)_{4} / \mathrm{CuI}$ as catalysts, in the presence of diisopropylamine, and heating for 1 hour at $80{ }^{\circ} \mathrm{C}$. The next steps include the deprotection of the two MOM-groups and the conversion of the phenols into the corresponding triflates for the subsequent metallo-catalyzed couplings. The seemingly obvious MOM-deprotection step is actually problematic because of the possible addition of the phenol to the alkyne and formation of an undesired benzofurane derivative. After meticulous optimization of this deprotection step with the use of a Lewis acid at low temperature $\left(\mathrm{BCl}_{3}, \mathrm{CH}_{2} \mathrm{Cl}_{2},-78^{\circ} \mathrm{C}\right)$ and subsequent triflation with phenyltriflimide, the desired compound $\mathbf{4}$ was isolated in $82 \%$ yield over two steps. The following step includes a double Suzuki-Miyaura coupling reaction between the bistriflate $\mathbf{4}$ and the boronic ester 5 . $^{6 \mathrm{f}}$ The best reaction conditions consist in $10 \mathrm{~mol} \% \mathrm{Pd}(\mathrm{SPhos})_{2} \mathrm{Cl}_{2}$ catalyst, cesium carbonate as a base in a $\mathrm{THF} / \mathrm{H}_{2} \mathrm{O}$ solvents mixture, and heating for 1 hour at $80{ }^{\circ} \mathrm{C}$. After deprotection of the triisopropylsilyl ether group with tetrabutylammonium fluoride, the triyne $\mathbf{6}$ was finally isolated in $79 \%$ yield (3.4 grams) over the last two
Scheme 1. Synthesis of the key intermediate 6

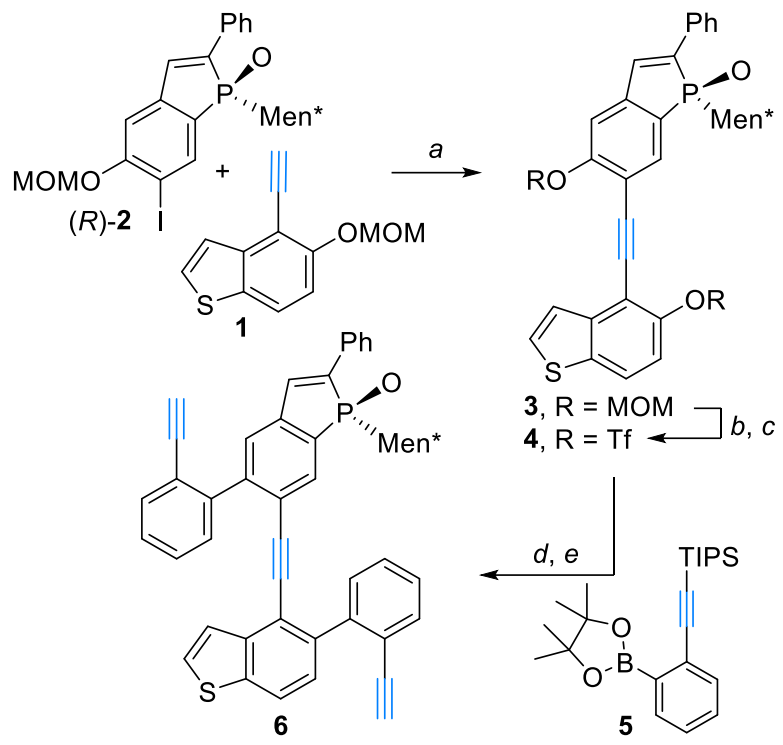

a. $\mathrm{Pd}\left(\mathrm{PPh}_{3}\right)_{4}(2 \mathrm{~mol} \%)$, Cul $(4 \mathrm{~mol} \%)$, DIPA, $80^{\circ} \mathrm{C}, 1 \mathrm{~h}, 91 \%$; b. $\mathrm{BCl}_{3}, \mathrm{CH}_{2} \mathrm{Cl}_{2}-78^{\circ} \mathrm{C}, 0.5 \mathrm{~h}$; c. PhNTf $\mathrm{Pt}_{2}, \mathrm{Et}_{3} \mathrm{~N}, \mathrm{DMF}, \mathrm{rt}, 4 \mathrm{~h}$, $82 \%$; d. 5, Pd(SPhos) ${ }_{2} \mathrm{Cl}_{2}(10 \mathrm{~mol} \%), \mathrm{Cs}_{2} \mathrm{CO}_{3}, \mathrm{THF} / \mathrm{H}_{2} \mathrm{O}$ (10/1), $80^{\circ} \mathrm{C}, 1 \mathrm{~h}$; e. TBAF, THF, rt, 2 h, $79 \%$ (2 steps).

steps. The next step, i.e. the formation of the phosphahelicene backbone, was accomplished in the presence of $\mathrm{Ni}(\operatorname{cod})_{2}(20$ $\mathrm{mol} \%$ ) and triphenylphosphine (40 $\mathrm{mol} \%)$, in THF at room temperature for 30 minutes (Scheme 2). Starting with $2.4 \mathrm{~g}$ of triyne 6 , we isolated $0.91 \mathrm{~g}$ of the HelPhos-V oxide $(M)-7$ $\left\{[\alpha]_{\mathrm{D}}-1099\left(\mathrm{c} 1, \mathrm{CHCl}_{3}\right),{ }^{31} \mathrm{P}\right.$ NMR $\left.\delta=59 \mathrm{ppm}\right\}$ and $1.03 \mathrm{~g}$ of $(P)-7\left\{[\alpha]_{\mathrm{D}}+1635\left(\mathrm{c} 1, \mathrm{CHCl}_{3}\right),{ }^{31} \mathrm{P} \mathrm{NMR} \delta=56 \mathrm{ppm}\right\}$. These two epimers, with opposite helical configurations, have been obtained in a 47:53 ratio.

Scheme 2. Synthesis and X-ray Crystal Structures of $(M)-7$ (CCDC 1984557) and (P)-7 (CCDC 1984558)

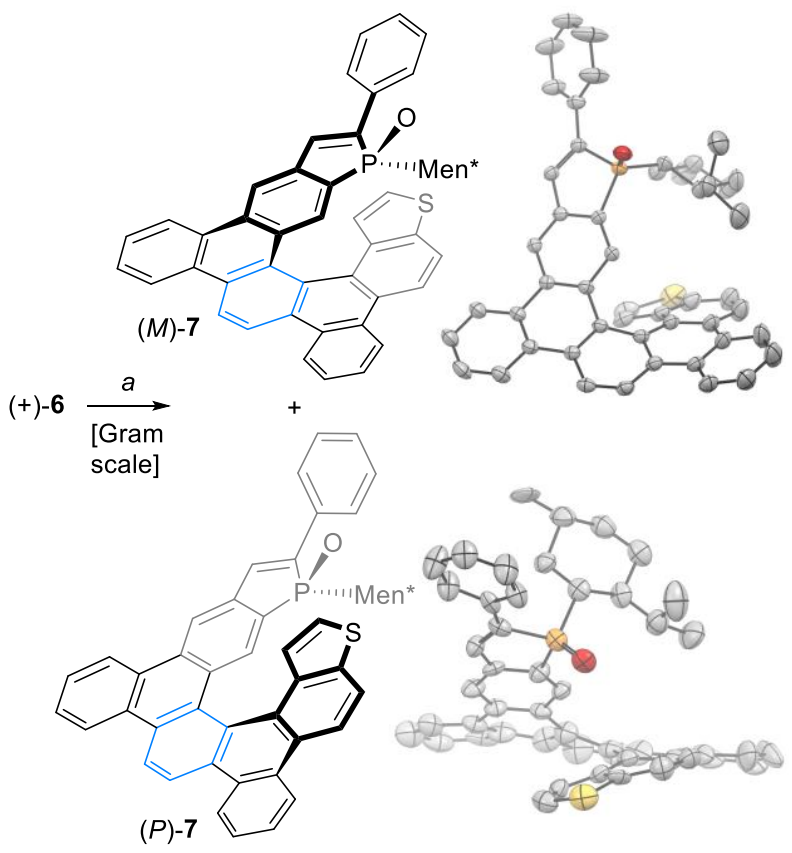

a. $\mathrm{Ni}(\mathrm{cod})_{2}(20 \mathrm{~mol} \%), \mathrm{PPh}_{3}(40 \mathrm{~mol} \%), \mathrm{THF}, \mathrm{rt}, 30 \mathrm{~min}, 81 \%$, $(M)-7 /(P)-7=47 / 53$ 
With the aim to increase the $(M) /(P)$ diastereoisomeric ratio in the cyclotrimerization process, we screened several other monodentate phosphines $\left(\mathrm{PMe}_{2} \mathrm{Ph}, \mathrm{PCy}_{3}, \mathrm{P}\left(p \mathrm{~F}-\mathrm{C}_{6} \mathrm{H}_{4}\right)_{3}\right)$, diphosphines (dppf, XantPhos) and triphenylphosphite. Unfortunately, we did not manage to increase the diastereoisomer ratio over a 60/40 ratio. The use of chiral phosphines such as $(R)$-QUINAP and $(S)$-QUINAP ${ }^{6 f}$ with a possible beneficial «match effect» between the chiral phosphindole and the chiral catalyst did not improve these results.

It is quite remarkable that gram-quantities of enantiopure phosphathiahelicenes $(M)-7$ and $(P)-7$ are available with this robust synthetic pathway $48 \%$ overall yield starting from compounds 1 and 2). Noteworthy, the two epimers have been separated easily by flash chromatography on silica gel, and the absolute configuration of the helicenes was assigned by X-ray diffraction studies (Scheme 2).

In the next step, we investigated the bromination reaction as a representative example of selective functionalization of the phosphathiahelicene $(P)-7$ (Scheme 3). Bromination of the terminal thiophene moiety of $(P)-7$ was achieved in $72 \%$ yield with the use of $N$-bromosuccinimide in DMF, leading to the alpha-bromo-thiahelicene $\mathbf{8}$ as the unique regioisomer. Subsequently, a Suzuki-Miyaura coupling reaction on $(P)-\mathbf{8}$ allowed the introduction of a phenyl group, in $81 \%$ yield (compound 9). On the other hand, a $\mathrm{Pd} / \mathrm{Cu}$-catalyzed Sonogashira coupling furnished the corresponding phenylethynyl-substituted helicene $(P)-\mathbf{1 0}$ in $90 \%$ yield.

Overall, these experiments confirm that the synthetic strategy benefits from both the high yielding $[2+2+2]$ cyclotrimerization approach and the selective and flexible late-stage functionalization of the terminal thiophene ring.

Scheme 3. Selective Functionalization of Phosphahelicene $(P)-7$

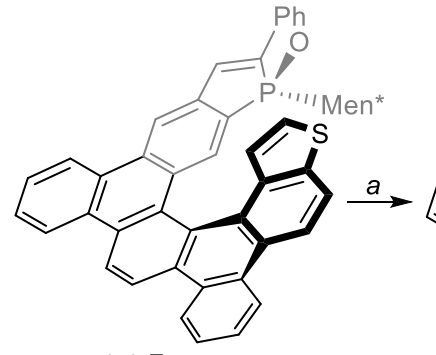

$(P)-7$

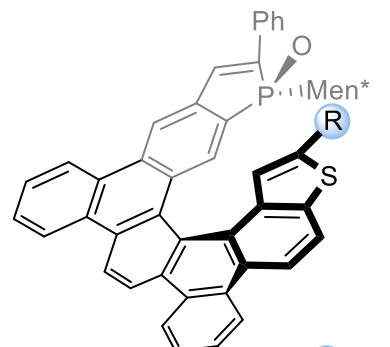

$(P)-8 \mathrm{R}=\mathrm{Br}$

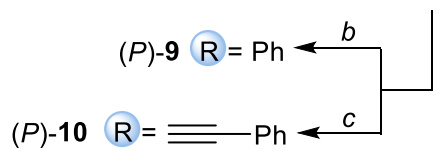

a. NBS, DMF, rt, $72 \% ; b$. $\mathrm{PhB}(\mathrm{OH})_{2}, \mathrm{Pd}\left(\mathrm{PPh}_{3}\right)_{4}(5 \mathrm{~mol} \%)$, $\mathrm{Na}_{2} \mathrm{CO}_{3}, \mathrm{THF} / \mathrm{H}_{2} \mathrm{O} / \mathrm{EtOH}(2 / 2 / 1), 85{ }^{\circ} \mathrm{C}, 5 \mathrm{~h}, 81 \%$; c. $\mathrm{PhC} \equiv \mathrm{CH}, \operatorname{Pd}\left(\mathrm{PPh}_{3}\right)_{4}(8 \mathrm{~mol} \%)$, Cul $(16 \mathrm{~mol} \%)$, DIPA/DMF (1/1), $80^{\circ} \mathrm{C}, 16 \mathrm{~h}, 90 \%$.

In the past two decades, gold-catalysis proved to be a very powerful and versatile tool for the synthesis of densely functionalized compounds. Notably, activation of unsaturated bonds, such as alkynes or allenes, by cationic gold(I) complexes easily delivers structurally complex polycyclic scaffolds. ${ }^{8}$ Thus, the demonstrated efficiency of phosphahelicenes as chiral ligands in some of these reactions, led us to envisage to convert the new HelPhos-V ligands to the corresponding gold(I)-complexes and to investigate their catalytic uses.

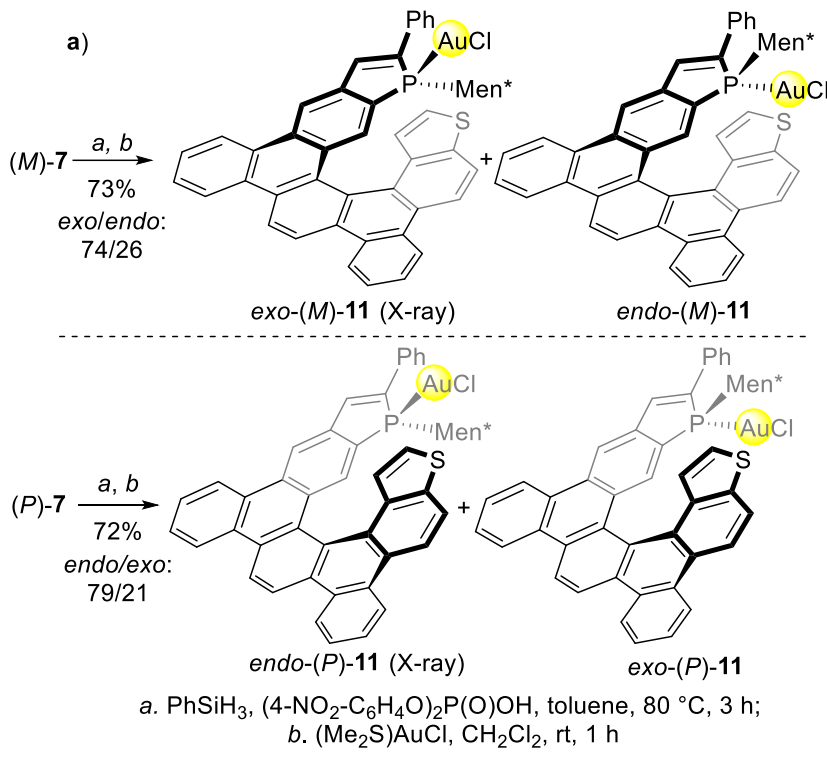

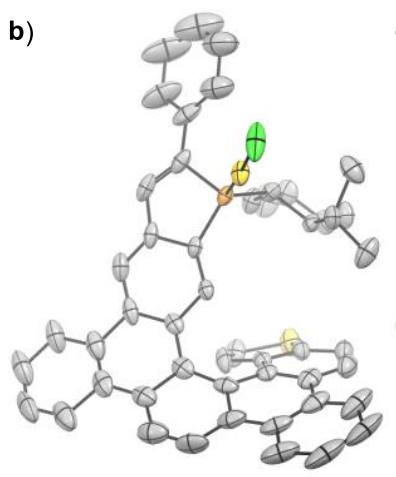

exo-(M)-11

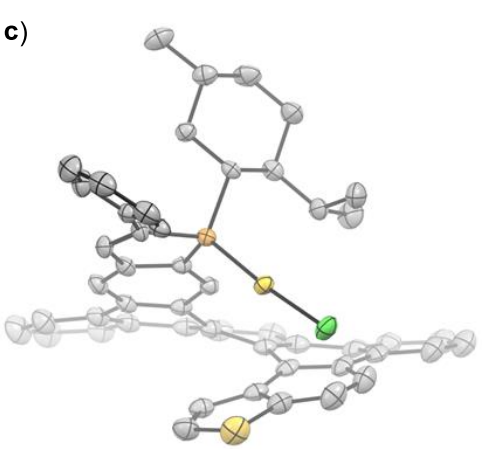

endo- $(P)-11$

Figure 3. a) Synthesis of the gold(I)-complexes 11. b) and c) $X$ ray Crystal Structures of exo-(M)-11 (CCDC 1984559) and endo$(P)-11$ (CCDC 1984560), respectively. Ellipsoids are drawn at the $50 \%$ probability level, $\mathrm{H}$ atoms are not shown for clarity.

Phosphine oxide $(M)$-7 was reduced with phenylsilane and the corresponding epimeric mixture of trivalent phosphines ${ }^{9}$ was complexed with gold, to isolate the two diastereoisomeric exo$(M)-11\left\{[\alpha]_{\mathrm{D}}-1444\left(\mathrm{c} 1, \mathrm{CHCl}_{3}\right),{ }^{31} \mathrm{P}\right.$ NMR $\left.\delta=24 \mathrm{ppm}\right\}$ and endo- $(M)-11\left\{[\alpha]_{\mathrm{D}}-1040\left(\mathrm{c} 1, \mathrm{CHCl}_{3}\right),{ }^{31} \mathrm{P} \mathrm{NMR} \delta=30 \mathrm{ppm}\right\}$ complexes in $73 \%$ yield and a 74/26 ratio (Figure $3 \mathrm{a}$ ). Both isomers were isolated by column chromatography on silica gel and fully characterized by NMR $\left({ }^{1} \mathrm{H},{ }^{13} \mathrm{C},{ }^{31} \mathrm{P}\right)$. The stereochemistry of the major isomer exo- $(M)-\mathbf{1 1}$ has been assigned by X-ray diffraction studies (Figure $3 b$ ). In this complex, the gold atom is located on the external face of the helical scaffold (exo-arrangement). Analogously, the reduction-complexation procedure was applied to $(P)-7$, and furnished a 79/21 mixture of phosphahelicene-gold complexes in $72 \%$ yield. X-ray analysis showed that the major isomer displays an endoarrangement (endo- $(P)-\mathbf{1 1})$, the gold atom being oriented toward the helical pocket (Figure $3 \mathrm{c}$ ).

Finally, starting from the substituted phosphahelicenes 9 and 10, the corresponding gold-complexes endo- $(P)-12$ and endo$(P)$-13 were isolated after the phosphine oxide reduction/gold complexation sequence.

The newly synthesized chiral gold(I) complexes 11-13 were evaluated in a benchmark catalytic reaction, namely the cycloisomerization of the 1,6 -enyne 14 (Table 1 ). ${ }^{10}$ In this reaction, high enantioselectivity levels were already obtained with 
bis-gold complexes of axially chiral diphosphines, ${ }^{10 \mathrm{c}}$ monogold complexes of chiral phosphites ${ }^{10 \mathrm{~d}}$ and phosphahelicenes. ${ }^{7}$ We first compared the four diastereoisomeric gold complexes exolendo- $(M) /(P)-11$ (entries 1-4). In both the $(P)$ - and $(M)$ series, the "endo" isomers gave better conversions and enantiomeric excesses than the "exo" isomers. This can be explained easily by the encapsulation of the metal center in the chiral pocket, in the "endo" isomers. The endo-cationic gold complex is thus protected by the helical backbone towards possible catalyst decay and it also benefits, in terms of chiral induction, from a highly asymmetric environment. Furthermore, when comparing entries 2 and 4 it appears that a positive synergistic effect exists between the chiral $L$-menthyl group and the $(P)$ configured phosphahelicene, leading to the best results in terms of enantioselectivity with the endo- $(P)-\mathbf{1 1}$ isomer. In the presence of this precatalyst, and after activation with $\mathrm{AgPF}_{6}$ in toluene at room temperature, the reaction reached full conversion after $20 \mathrm{~h}$ and an $86 \%$ enantiomeric excess (entry 4). In order to optimize this result, with the chiral precatalyst endo$(P)-\mathbf{1 1}$, we next screened different silver salts $\operatorname{AgX}\left(\mathrm{X}=\mathrm{BF}_{4}\right.$, OTf, $\mathrm{NTf}_{2}, \mathrm{SbF}_{6}$ ) and solvents (xylene, dichloromethane, THF and acetone). However, neither these modifications nor the decrease of the reaction temperature to $0{ }^{\circ} \mathrm{C}$ allowed any improvements (see Supporting Information for details).

After these preliminary optimization studies, and according to our working hypothesis, we have investigated the possible effects of the remote R-substituents of the thiophene unit on the catalytic behavior. If the introduction of a phenylsubstituent in endo- $(P)-\mathbf{1 2}$ does not show positive effects on the enantiomeric excess $(83 \%$ ee, entry 5$)$, the best result was obtained with the gold(I) catalyst endo- $(P)-\mathbf{1 3}$, which displays

Table 1. Evaluation of the HelPhos-V Ligands in Gold Catalysis

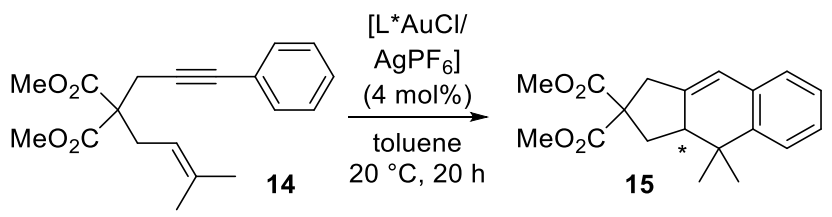

$\begin{array}{llll}\text { entry } & {[\mathrm{L} * \mathrm{AuCl}]} & \text { Conv. }(\%)^{\mathrm{a}} & \text { ee }(\%)^{\mathrm{b}} \\ 1 & \text { exo- }(M)-\mathbf{1 1} & 17 & 23(-) \\ 2 & \text { endo- }(M)-\mathbf{1 1} & 39 & 34(-) \\ 3 & \text { exo- }(P)-\mathbf{1 1} & 56 & 37(+) \\ 4 & \text { endo- }(P)-\mathbf{1 1} & 100 & 86(+) \\ 5 & \text { endo- }(P)-\mathbf{1 2} & 45 & 83(+) \\ 6 & \text { endo- }(P)-\mathbf{1 3} & 100(92) & 94(+)\end{array}$

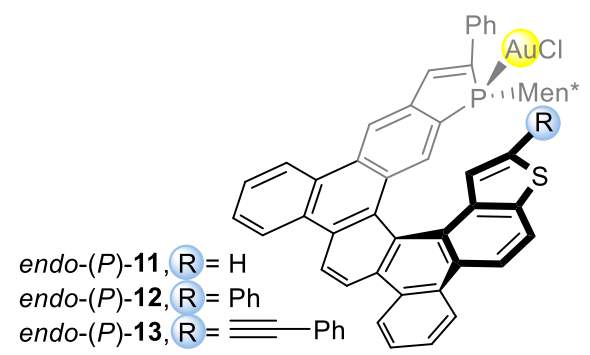

${ }^{a}$ Determined by ${ }^{1} \mathrm{H}$ NMR using trimethoxybenzene as internal standard. Isolated yield in parentheses. ${ }^{b}$ Determined by HPLC on a chiral stationary phase. a $\mathrm{PhC} \equiv \mathrm{C}$ - substituent on the terminal thiophene ring (92\% isolated yield, $94 \%$ ee, entry 6). This last result shows undeniably the positive contribution of the additional phenylethynyl substituent on the phosphathiahelicene backbone. This finetuning of the ligand allows us to attain the best enantioselectivity obtained so far with this substrate, to the best of our knowledge. ${ }^{9}$ Overall, these preliminary catalytic tests demonstrate the potential of the new phosphahelicene scaffold, HelPhos-V, in gold(I) catalysis, both in terms of catalytic activity and chiral induction, and the additional opportunities offered by tuning its substitution pattern.

Next, to take full advantage from this potential, we decided to go beyond model catalytic reactions on known substrates and we turned our attention to some unprecedented gold-catalyzed transformation of indoles. Indeed, indole derivatives are known to afford numerous interesting polycyclic products under gold-catalysis. ${ }^{11,12}$ Notably, over the last few years we have been involved in the development of gold-catalyzed spirocyclizations of indoles, leading to a range of spirooxindoles and spiroindolenines. ${ }^{120-p}$ In particular, we disclosed recently the first regioselective spirocyclizations of the $\mathrm{N}$ propargyltryptamines $\mathbf{1 6}$ into $\mathrm{C} 2$-unsubstituted spiroindolenines (Scheme 4a). An enantioselective version of this reaction showed only moderate enantioselectivity, with the use of HelPhos-S-AuCl as the gold precatalyst (60\% ee). ${ }^{12 \mathrm{p}}$ Unfortunately, the newly developed gold catalysts endo-(P)-11 and $\mathbf{1 2}$ did not improve this result, highlighting again the challenge offered by this class of reactions when applied to terminal alkynes.

Scheme 4. Gold-Catalyzed Cyclizations of $N$-Propargyl and $\mathrm{N}$-Homoallenyl-Tryptamine Derivatives

a) Enantioselective spirocyclization of $\mathbf{N}$-propargyltryptamine

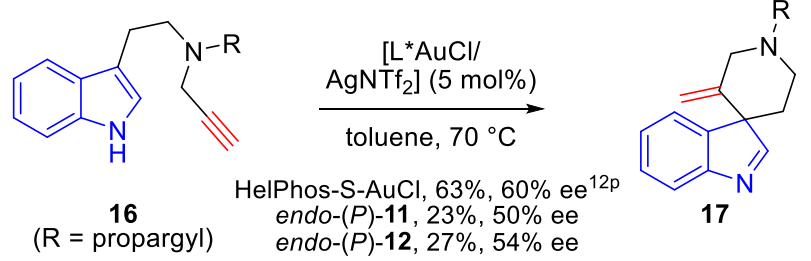

b) Tandem 3,3-rearrangement/[2+2] cycloaddition $^{13 a, b}$

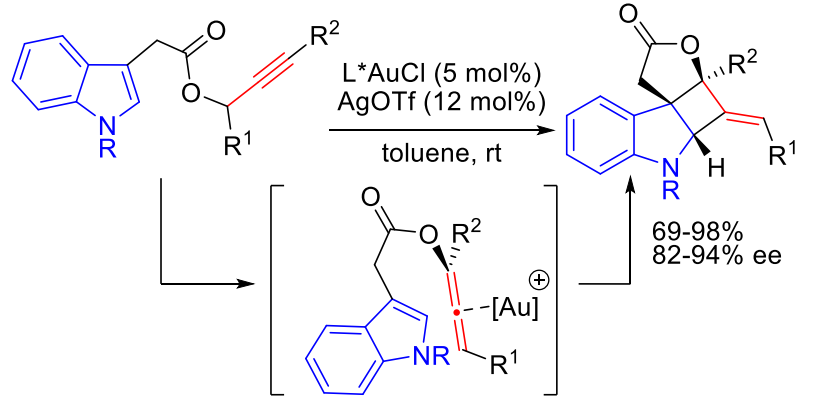

c) Gold-catalyzed [2+2] cyclization of $\mathbf{N}$-homoallenyltryptamines

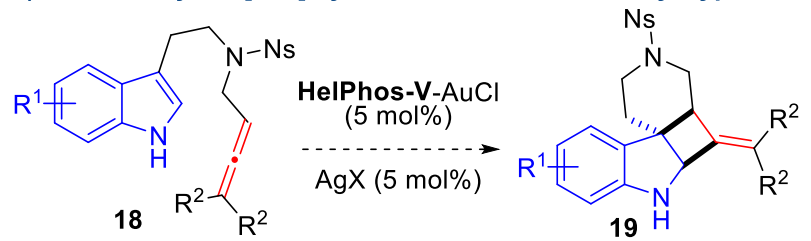

On the other hand, allenes, which display a different coordination mode and geometry, have been more successful in enantioselective gold-catalysis involving indoles in hydroarylation 
reactions. Our attention was in particular driven by the reaction depicted in Scheme 4b that involves an indolyl-allene as the key intermediate. It combines an $\mathrm{Au}(\mathrm{I})$-catalyzed 3,3rearrangement / [2+2] cycloaddition of a propargylic ester, leading to 2,3-indoline-fused cyclobutanes. ${ }^{13 a}$ The enantioselective version of this reaction was also developed using chiral acyclic diaminocarbene ligands. ${ }^{13 b, 14}$ We hypothesized that tryptamines containing an $N$-homoallenyl fragment, such as 18, might undergo analogous intramolecular [2+2] cyclisations under gold catalysis and could afford the 2,3indolinecyclobutanes 19 (Scheme 4c).

We were pleased to see that our first attempts using complex endo- $(P)-\mathbf{1 1}$ and $\mathrm{AgNTf}_{2}$ afforded the desired polycyclic indoline-fused cyclobutane 19a in a good $76 \%$ yield and $90 \%$ ee (Scheme 5). A quick screening of the reaction conditions revealed that $\mathrm{AgNTf}_{2}$ was the most suitable chloride scavenger from the gold precatalyst, for reactions carried out in toluene at room temperature. The product 19a was fully characterized by NMR spectroscopy and the skeletal arrangement and the absolute stereochemistry were ascertained by X-ray diffraction studies.

Scheme 5. [HelPhos-V-AuCl]-Catalyzed Cyclizations of Substrates 18a-e
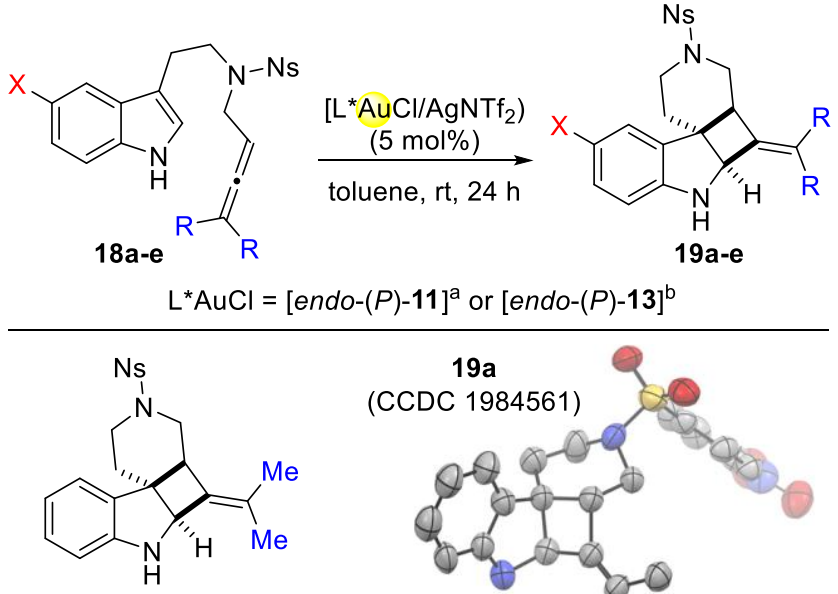

$19 a, 76 \%, 90 \% \mathrm{ee}^{\mathrm{a}}$ $(82 \%, 91 \% \text { ee })^{\mathrm{b}}$<smiles>CC(C)=C1[C@H]2CN(S)CC[C@@]23c2cc(C)ccc2N[C@H]13</smiles>

$19 b, 82 \%, 90 \% \mathrm{ee}^{\mathrm{b}}$<smiles>CC(C)=C1[C@H]2CN(SN)CC[C@@]23c2cc(Cl)ccc2N[C@H]13</smiles>

$19 d, 76 \%, 92 \% e^{a}$
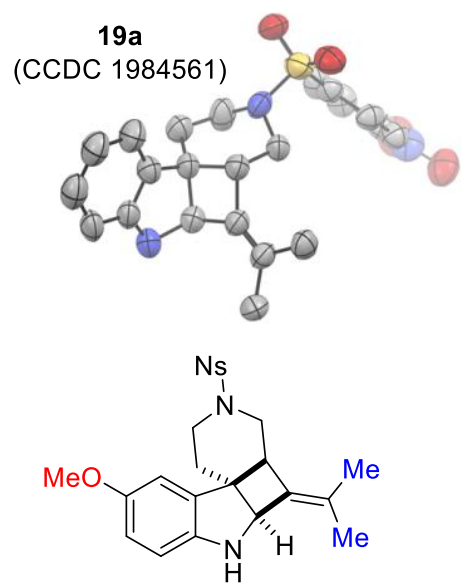

$19 \mathrm{c}, 55 \%, 88 \% \mathrm{ee}^{\mathrm{a}}$ $(35 \%, 93 \% \text { ee })^{\mathrm{b}}$

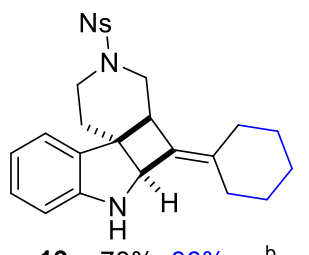

$19 e, 78 \%, 86 \%$ ee $^{b}$

Further experiments have been conducted then with the phenylethynyl-substituted gold-catalyst $(P)$-13, and the corresponding tetracyclic product 19a was isolated in $82 \%$ yield and $91 \%$ ee (Scheme 5). Based on these highly promising results, the scope of the reaction has been extended to a few other substrates, using either pre-catalyst endo- $(P)-\mathbf{1 1}$ or endo$(P)$-13. Modification of the indole moiety with either electron donating or electron withdrawing groups gave the corresponding products $\mathbf{1 9 b}$-d in moderate to good yields and up to $93 \%$ ee. ${ }^{15}$ In some instances, the yield could be slightly increased with the use of the endo- $(P)-\mathbf{1 1}$ catalyst (see compound 19c), but generally the best compromise between yield and ee was obtained with $(P)$-13. Finally, a cyclohexylidene-allene derivative was engaged in the Au-catalyzed transformation to furnish the desired product 19e in $78 \%$ yield and $86 \%$ ee.

Concerning the mechanism of this transformation, we can postulate that it starts with the activation of the allene function of substrate $\mathbf{1 8}$ by the cationic gold(I) complex (Scheme 6, intermediate I). Formation of the first carbon-carbon bond by nucleophilic addition of indole to the activated allene leads to the spiranic intermediate II with concomitant dearomatization of the indole. Analogous 6-exo cyclizations involving nucleophilic indoles and tethered unsaturated functions, activated by gold, are quite common with this class of tryptamine derivatives. ${ }^{11,12}$ A consecutive intramolecular addition of the vinylgold species to the indolenium electrophilic site then affords the 2,3-indoline-fused cyclobutane product 19, while releasing the active gold-complex.

Scheme 6. Proposed Mechanism

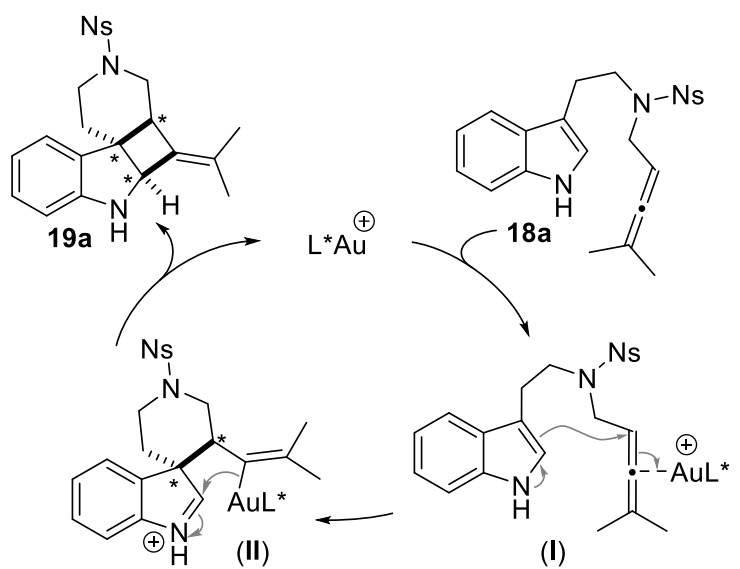

In summary, we have synthesized and characterized new phosphathiahelicenes and used them successfully as chiral ligands in a new gold-catalyzed transformation. Structurally complex polycyclic indole derivatives, with three contiguous stereogenic centers were isolated in good yields and up to $93 \%$ ee. The scalable and versatile synthesis of [HelPhos-V] ligands will enable us to finely tune the phosphahelicene ligands for further applications in enantioselective gold-catalysis.

\section{ASSOCIATED CONTENT}

Supporting Information. This material is available free of charge via the Internet at http://pubs.acs.org.

\section{AUTHOR INFORMATION}

\section{Corresponding Authors}

arnaud.voituriez@cnrs.fr xavier.guinchard@cnrs.fr

\section{Author Contributions}


All authors have given approval to the final version of the manuscript.

\section{Notes}

This article is dedicated to Dr. Jean-René Hamon (Rennes Institute of Chemical Sciences, France) on the occasion of his $65^{\text {th }}$ anniversary.

\section{ACKNOWLEDGMENT}

Authors acknowledge the support of the Institut de Chimie des Substances Naturelles (ICSN) and the Centre National de la Recherche Scientifique (CNRS). The "Indo-French Center for the Promotion of Advanced Research (IFCPAR/CEFIPRA, Project $\left.\mathrm{N}^{\circ} 5505-2,2016\right)$ is acknowledged for post-doctoral grant to Y.S.

\section{ABBREVIATIONS}

MOM, methoxymethyl; $\mathrm{PhNTf}_{2}$, phenyltriflimide; SPhos, 2dicyclohexylphosphino-2',6'-dimethoxybiphenyl; TIPS, triisopropylsilyl ether group; TBAF, tetrabutylammonium fluoride; cod, 1,5-cyclooctadiene; dppf, 1,1'-ferrocenediylbis(diphenylphosphine); XantPhos, 4,5-bis(diphenylphosphino)9,9-dimethylxanthene; NMR, Nuclear Magnetic Resonance; DMF, dimethylformamide; THF, tetrahydrofurane; QUINAP, 1(2-diphenylphosphino-1-naphthyl)isoquinoline.

\section{REFERENCES}

(1) (a) Shen, Y.; Chen, C.-F. Helicenes: Synthesis and Applications. Chem. Rev. 2012, 112, 1463-1535. (b) Gingras, M. One Hundred Years of Helicene Chemistry. Part 3: Applications and Properties of Carbohelicenes. Chem. Soc. Rev. 2013, 42, 1051-1095. (c) Saleh, N.; Shen, C.; Crassous, J. Helicene-Based Transition Metal Complexes: Synthesis, Properties and Applications. Chem. Sci. 2014, 5, 3680-3694. (d) Dhbaibi, K.; Favereau, L.; Crassous, J. Enantioenriched Helicenes and Helicenoids Containing Main-Group Elements (B, Si, N, P). Chem. Rev. 2019, 119, 8846-8953. (e) Zhao, W.-L.; Li, M.; Lu, H.-Y.; Chen, C.-F. Advances in Helicene Derivatives with Circularly Polarized Luminescence. Chem. Cотmun. 2019, 55, 13793-13803.

(2) For reviews, see: (a) Narcis, M. J.; Takenaka, N. Helical-Chiral Small Molecules in Asymmetric Catalysis. Eur. J. Org. Chem. 2014, 21-34. (b) Aillard, P.; Voituriez, A.; Marinetti, A. Helicene-Like Chiral Auxiliaries in Asymmetric Catalysis. Dalton Trans 2014, 43, 15263-15278. (c) Demmer, C. S.; Voituriez, A.; Marinetti, A. Catalytic Uses of Helicenes Displaying Phosphorus Functions. C. $R$. Chimie 2017, 20, 860-879. For some representative examples, see: (d) Reetz, M. T.; Sostmann, S. Kinetic Resolution in Pd-Catalyzed Allylic Substitution using the Helical PHelix Ligand. J. Organomet. Chem. 2000, 603, 105-109. (e) Teply, F.; Stará, I. G.; Starý, I.; Kollarovic, A.; Saman, D.; Vyskocil, S.; Fiedler, P. Synthesis of 3Hexahelicenol and its Transformation to 3-Hexahelicenylamines, Diphenylphosphine, Methyl Carboxylate, and Dimethylthiocarbamate. J. Org. Chem. 2003, 68, 5193-5197. (f) Nakano, D.; Yamaguchi, M. Enantioselective Hydrogenation of Itaconate using Rhodium Bihelicenol Phosphite Complex. Matched/Mismatched Phenomena between Helical and Axial Chirality. Tetrahedron Letters 2003, 44, 4969-4971. (g) Tsujihara, T.; Inada-Nozaki, N.; Takehara, T.; Zhou, D.-Y.; Suzuki, T.; Kawano, T. Nickel-Catalyzed Construction of Chiral 1-[6]Helicenols and Application in the Synthesis of [6]Helicene-Based Phosphinite Ligands. Eur. J. Org. Chem. 2016, 4948-4952. (h) Yamamoto, K.; Shimizu, T.; Igawa, K.; Tomooka, K.; Hirai, G.; Suemune, H.; Usui, K. Rational Design and Synthesis of [5]Helicene-Derived Phosphine Ligands and Their Application in PdCatalyzed Asymmetric Reactions. Sci. Rep. 2016, 6, 36211-36218.

(3) (a) Fukawa, N.; Osaka, T.; Noguchi, K.; Tanaka, K. Asymmetric Synthesis and Photophysical Properties of Benzopyrano- or Naphthopyrano-Fused Helical Phosphafluorenes. Org. Lett. 2010, 12,
1324-1327; (b) Sawada, Y.; Furumi, S.; Takai, A.; Takeuchi, M.; Noguchi, K.; Tanaka, K. Rhodium-Catalyzed Enantioselective Synthesis, Crystal Structures, and Photophysical Properties of Helically Chiral 1,1 '-Bitriphenylenes. J. Am. Chem. Soc. 2012, 134, 4080-4083; (c) Nakano, K.; Oyama, H.; Nishimura, Y.; Nakasako, S.; Nozaki, K. $\lambda^{5}$-Phospha[7]helicenes: Synthesis, Properties, and Columnar Aggregation with One-Way Chirality. Angew. Chem. Int. Ed. 2012, 51, 695-699; (d) Rahman, M. S.; Yoshikai, N. Synthesis and Properties of Phospha[5]helicenes Bearing an Inner-Rim Phosphorus Center. Org. Lett. 2019, 21, 3232-3236.

(4) (a) Yavari, K.; Moussa, S.; Ben Hassine, B.; Retailleau, P.; Voituriez, A.; Marinetti, A. $1 H$-Phosphindoles as Structural Units in the Synthesis of Chiral Helicenes. Angew. Chem. Int. Ed. 2012, 51 , 6748-6752. (b) Yavari, K.; Aillard, P.; Zhang, Y.; Nuter, F.; Retailleau, P.; Voituriez, A.; Marinetti, A. Helicenes with Embedded Phosphole Units in Enantioselective Gold Catalysis. Angew. Chem. Int Ed. 2014, 53, 861-865. (c) Aillard, P.; Voituriez, A.; Dova, D.; Cauteruccio, S.; Licandro, E.; Marinetti, A. Phosphathiahelicenes: Synthesis and Uses in Enantioselective Gold Catalysis. Chem. Eur. J. 2014, 20, 12373-12376. (d) Aillard, P.; Retailleau, P.; Voituriez, A.; Marinetti, A. Synthesis of New Phosphahelicene Scaffolds and Development of Gold(I)-Catalyzed Enantioselective Allenene Cyclizations. Chem. Eur. J. 2015, 21, 11989-11993. (e) Gicquel, M.; Zhang, Y.; Aillard, P.; Retailleau, P.; Voituriez, A.; Marinetti, A. Phosphahelicenes in Asymmetric Organocatalysis: [3+2] Cyclizations of $\gamma-$ Substituted Allenes and Electron-Poor Olefins. Angew. Chem. Int. Ed. 2015, 54, 5470-5473.

(5) Hoffmann, N. Photochemical Reactions Applied to the Synthesis of Helicenes and Helicene-like Compounds. J. Photochem. Photobiol. C 2014, 19, 1-19.

(6) (a) Stará, I. G.; Starý, I. Helically Chiral Aromatics: The Synthesis of Helicenes by $[2+2+2]$ Cycloisomerization of $\pi$-Electron Systems. Acc. Chem. Res. 2020, 53, 144-158. (b) Stará, I. G.; Starý, I.; Kollarovic, A.; Teply, F.; Šaman, D.; Tichy, M. A Novel Strategy for the Synthesis of Molecules with Helical Chirality. Intramolecular $[2+2+2]$ Cycloisomerization of Triynes under Cobalt Catalysis. $J$. Org. Chem. 1998, 63, 4046-4050. (c) Teply, F.; Stará, I. G.; Starý, I.; Kollarovic, A.; Saman, D.; Rulisek, L.; Fiedler, P. Synthesis of [5]-, [6]-, and [7]-Helicene via $\mathrm{Ni}(0)-$ or $\mathrm{Co}(\mathrm{I})$-Catalyzed Isomerization of Aromatic cis,cis-Dienetriynes. J. Am. Chem. Soc. 2002, 124, 9175-9180. (d) Tanaka, K.; Kamisawa, A.; Suda, T.; Noguchi, K.; Hirano, M. Rh-Catalyzed Synthesis of Helically Chiral and Laddertype Molecules via $[2+2+2]$ and formal $[2+1+2+1]$ Cycloadditions Involving C-C Triple Bond Cleavage. J. Am. Chem. Soc. 2007, 129, 12078-12079. (e) Žádný, J.; Jančař́ík, A.; Andronova, A.; Šámal, M.; Vacek Chocholoušová, J.; Vacek, J.; Pohl, R.; Šaman, D.; Císařová, I.; Stará, I. G.; Starý, I. A General Approach to Optically Pure [5]-, [6]-, and [7]-Heterohelicenes. Angew. Chem. Int. Ed. 2012, 51, 5857-5861. (f) Jančařík, A.; Rybáček, J.; Cocq, K.; Vacek Chocholoušová, J.; Vacek, J.; Pohl, R.; Bednárová, L.; Fiedler, P.; Císařová, I.; Stará, I. G.; Starý, I. Rapid Access to Dibenzohelicenes and their Functionalized Derivatives. Angew. Chem. Int. Ed. 2013, 52, 9970-9975. (g) Samal, M.; Chercheja, S.; Rybacek, J.; Chocholousova, J. V.; Vacek, J.; Bednarova, L.; Saman, D.; Stará, I. G.; Starý, I. An Ultimate Stereocontrol in Asymmetric Synthesis of Optically Pure Fully Aromatic Helicenes. J. Am. Chem. Soc. 2015, 137, 8469-8474.

(7) Aillard, P.; Dova, D.; Magné, V.; Retailleau, P.; Cauteruccio, S.; Licandro, E.; Voituriez, A.; Marinetti, A. The Synthesis of Substituted Phosphathiahelicenes via Regioselective Bromination of a Preformed Helical Scaffold: a New Approach to Modular Ligands for Enantioselective Gold-Catalysis. Chem. Commun. 2016, 52, 10984-10987.

(8) For reviews on gold-catalysis, see: (a) Dorel, R.; Echavarren, A. M. Gold(I)-Catalyzed Activation of Alkynes for the Construction of Molecular Complexity. Chem. Rev. 2015, 115, 9028-9072. (b) Wei, Y.; Shi, M. Divergent Synthesis of Carbo- and Heterocycles via Gold-Catalyzed Reactions. ACS Catalysis 2016, 6, 2515-2524. (c) Asiri, A. M.; Hashmi, A. S. K. Gold-Catalysed Reactions of Diynes. Chem. Soc. Rev. 2016, 45, 4471-4503. (d) Pflasterer, D.; Hashmi, A. S. K. Gold Catalysis in Total Synthesis - Recent Achievements. 
Chem. Soc. Rev. 2016, 45, 1331-1367. (e) Marín-Luna, M.; Faza, O. N.; López, C. S. Gold-Catalyzed Homogeneous (Cyclo)Isomerization Reactions. Front. Chem. 2019, 7, 296. (f) Lu, Z.; Hammond, G. B.; $\mathrm{Xu}$, B. Improving Homogeneous Cationic Gold Catalysis through a Mechanism-Based Approach. Acc. Chem. Res. 2019, 52, 1275-1288. (g) Mato, M.; García-Morales, C.; Echavarren, A. M. Generation of Gold(I) Carbenes by Retro-Buchner Reaction: From Cyclopropanes to Natural Products Synthesis. Chem. Cat. Chem. 2019, 11, 53-72. (h) Mascareñas, J. L.; Varela, I.; López, F. Allenes and Derivatives in Gold(I) - and Platinum(II)-Catalyzed Formal Cycloadditions. Acc. Chem. Res. 2019, 52, 465-479.

(9) Trivalent P-stereogenic phospholes are known to be configurationally unstable at room temperature. For a leading reference, see: Egan, W.; Tang, R.; Zon, G.; Mislow, K. Barriers to Pyramidal Inversion at Phosphorus in Phospholes, Phosphindoles, and Dibenzophospholes. J. Am. Chem. Soc. 1971, 93, 6205-6216.

(10) (a) Nieto-Oberhuber, C.; Lopez, S.; Echavarren, A. M. Intramolecular [4 + 2] Cycloadditions of 1,3-Enynes or Arylalkynes with Alkenes with Highly Reactive Cationic Phosphine Au(I) Complexes. J. Am. Chem. Soc. 2005, 127, 6178-6179. (b) Nieto-Oberhuber, C.; Pérez-Galán, P.; Herrero-Gómez, E.; Lauterbach, T.; Rodríguez, C.; López, S.; Bour, C.; Rosellón, A.; Cárdenas, D. J.; Echavarren, A. M. Gold(I)-Catalyzed Intramolecular [4+2] Cycloadditions of $\mathrm{Ar}$ ylalkynes or 1,3-Enynes with Alkenes: Scope and Mechanism. J. Am. Chem. Soc. 2008, 130, 269-279. (c) Chao, C.-M.; Vitale, M. R.; Toullec, P. Y.; Genet, J.-P.; Michelet, V. Asymmetric Gold-Catalyzed Hydroarylation/Cyclization Reactions. Chem. Eur. J. 2009, 15, 1319-1323. (d) Delpont, N.; Escofet, I.; Perez-Galan, P.; Spiegl, D.; Raducan, M.; Bour, C.; Sinisi, R.; Echavarren, A. M. Modular Chiral Gold(I) Phosphite Complexes. Catal. Sci. Technol. 2013, 3, 3007-3012. (e) Zuccarello, G.; Mayans, J. G.; Escofet, I.; Scharnagel, D.; Kirillova, M. S.; Pérez-Jimeno, A. H.; Calleja, P.; Boothe, J. R.; Echavarren, A. M. Enantioselective Folding of Enynes by Gold(I) Catalysts with a Remote $\mathrm{C}_{2}$-Chiral Element. J. Am. Chem. Soc. 2019 $141,11858-11863$

(11) (a) Pirovano, V. Gold-Catalyzed Functionalization Reactions of Indole. Eur. J. Org. Chem. 2018, 1925-1945. (b) An, J.; Bandini, M. Gold-Catalyzed Dearomatization Reactions. Chimia 2018, 72, 610-613. (c) Huang, G.; Yin, B. Recent Developments in Transition Metal-Catalyzed Dearomative Cyclizations of Indoles as Dipolarophiles for the Construction of Indolines. Adv. Synth. Catal. 2019, 361 , 405-425. (d) Pirovano, V.; Abbiati, G.; Brambilla, E; and Rossi, E. Vinyl-/Furoindoles and Gold Catalysis: New Achievements and Future Perspectives for the Synthesis of Complex Indole Derivatives. Eur. J. Inorg. Chem. 2020, 962-977.

(12) Representative examples: (a) Ferrer, C.; Echavarren, A. M Gold-Catalyzed Intramolecular Reaction of Indoles with Alkynes: Facile Formation of Eight-Membered Rings and an Unexpected Allenylation. Angew. Chem. Int. Ed. 2006, 45, 1105-1109. (b) Zhang, Z.; Liu, C.; Kinder, R. E.; Han, X.; Qian, H.; Widenhoefer, R. A. Highly Active $\mathrm{Au}(\mathrm{I})$ Catalyst for the Intramolecular exoHydrofunctionalization of Allenes with Carbon, Nitrogen, and Oxygen Nucleophiles. J. Am. Chem. Soc. 2006, 128, 9066-9073. (c) Liu, Z.; Wasmuth, A. S.; Nelson, S. G. Au(I)-Catalyzed Annulation of Enantioenriched Allenes in the Enantioselective Total Synthesis of (-)-Rhazinilam. J. Am. Chem. Soc. 2006, 128, 10352-10353. (d) Ferrer, C.; Amijs, C. H. M.; Echavarren, A. M. Intra- and Intermolecular Reactions of Indoles with Alkynes Catalyzed by Gold. Chem. Eur. J. 2007, 13, 1358-1373. (e) Liu, C.; Widenhoefer, R. A. Gold(I)Catalyzed Intramolecular Enantioselective Hydroarylation of Allenes with Indoles. Org. Lett. 2007, 9, 1935-1938. (f) Tarselli, M. A.; Gagné, M. R. Gold(I)-Catalyzed Intramolecular Hydroarylation of Allenes. J. Org. Chem. 2008, 73, 2439-2441. (g) Barluenga, J.; Piedrafita, M.; Ballesteros, A.; Suárez-Sobrino, Á. L.; González, J. M. Gold-Catalyzed Annulations of 1-(2,3-Butadienyl)-1 $H$-Indole Derivatives. Chem. Eur. J. 2010, 16, 11827-11831. (h) Zeldin, R. M.; Toste, F. D. Synthesis of Flinderoles B and C by a Gold-Catalyzed Allene Hydroarylation. Chem. Sci. 2011, 2, 1706-1709. (i) Hashmi, A. S. K.; Yang, W.; Rominger, F. Gold-Catalysis: Highly Efficient and RegioSelective Carbonyl Migration in Alkynyl-Substituted Indole-3Carboxamides Leading to Azepino[3,4-b]indol-1-ones. Adv. Synth.
Catal. 2012, 354, 1273-1279. (j) Chen, B.; Fan, W.; Chai, G.; Ma, S. Electronic Effect Directed Au(I)-Catalyzed Cyclic C2-H Bond Functionalization of 3-Allenylindoles. Org. Lett. 2012, 14, 3616-3619. (k) Bandini, M.; Bottoni, A.; Chiarucci, M.; Cera, G.; Miscione, G. P. Mechanistic Insights into Enantioselective Gold-Catalyzed Allylation of Indoles with Alcohols: The Counterion Effect. J. Am. Chem. Soc. 2012, 134, 20690-20700. (1) Álvarez, E.; García-García, P.; Fernández-Rodríguez, M. A.; Sanz, R. Regioselective Synthesis of Elusive 4,9-Dihydro- $1 H$-Carbazoles by Gold-Catalyzed Cycloisomerization of 3-Allenylmethylindoles. J. Org. Chem. 2013, 78, 9758-9771. (m) Zi, W.; Wu, H.; Toste, F. D. Gold(I)-Catalyzed Dearomative Rautenstrauch Rearrangement: Enantioselective Access to Cyclopenta[b]indoles. J. Am. Chem. Soc. 2015, 137, 3225-3228. (n) Zheng, N.; Chang, Y.-Y.; Zhang, L.-J.; Gong, J.-X.; Yang, Z. Gold-Catalyzed Intramolecular Tandem Cyclization of Indole-Ynamides: Diastereoselective Synthesis of Spirocyclic Pyrrolidinoindolines. Chem. Asian J. 2016, 11, 371-375. (o) Magné, V.; Blanchard, F.; Marinetti, A.; Voituriez, A.; Guinchard, X. Synthesis of Spiro[piperidine-3,3'oxindoles] via Gold(I)-Catalyzed Dearomatization of $N$-Propargyland $\mathrm{N}$-Homoallenyl-2-bromotryptamines. Adv. Synth. Catal. 2016, 358, 3355-3361. (p) Magné, V.; Marinetti, A.; Gandon, V.; Voituriez, A.; Guinchard, X. Synthesis of Spiroindolenines via Regioselective Gold(I)-Catalyzed Cyclizations of $N$-Propargyl Tryptamines. Adv. Synth. Catal. 2017, 359, 4036-4042. (q) Magné, V.; Lorton, C.; Marinetti, A.; Guinchard, X.; Voituriez, A. Short Enantioselective Total Synthesis of (-)-Rhazinilam Using a Gold(I)-Catalyzed Cyclization. Org. Lett. 2017, 19, 4794-4797. (r) Glinsky-Olivier, N.; Retailleau, P.; Guinchard, X. Gold-Catalyzed Synthesis of Spirofused Indoloquinuclidines. Eur. J. Org. Chem. 2018, 5823-5829. (s) Zhang, Y.-Y.; Wei, Y.; Shi, M. Catalyst-Controlled Product Selectivity for Cycloaddition of Bis(indol-3-yl)-allenes to Fused Spiroindolines and Mechanistic Studies. Org. Lett. 2019, 21, 8250-8255. (t) Zhang, Y.Y.; Wei, Y.; Shi, M. Gold(I)-Catalyzed Enantioselective Synthesis of Polycyclic Indoline Skeletons and Enantiomerically Enriched $\beta$ Substituted Tryptamine-Allenes by Kinetic Resolution. Chem. Commun. 2019, 55, 4210-4213. (u) Wu, W.-T.; Ding, L.; Zhang, L.; You, S.-L. Gold-Catalyzed Intramolecular Dearomatization Reactions of Indoles for the Synthesis of Spiroindolenines and Spiroindolines. Org. Lett. 2020, 22, 1233-1238.

(13) (a) Zhang, L. Tandem Au-Catalyzed 3,3-Rearrangement-[2 + 2] Cycloadditions of Propargylic Esters: Expeditious Access to Highly Functionalized 2,3-Indoline-Fused Cyclobutanes. J. Am. Chem. Soc. 2005, 127, 16804-16805. (b) Niemeyer, Z. L.; Pindi, S.; Khrakovsky, D. A.; Kuzniewski, C. N.; Hong, C. M.; Joyce, L. A.; Sigman, M. S.; Toste, F. D. Parameterization of Acyclic Diaminocarbene Ligands Applied to a Gold(I)-Catalyzed Enantioselective Tandem Rearrangement/Cyclization. $J$. Am. Chem. Soc. 2017, 139, 12943-12946. For the use of of indolyl-allene substrates, see: (c) Mei, L.-Y.; Wei, Y.; Tang, X.-Y.; Shi, M. Catalyst-Dependent Stereodivergent and Regioselective Synthesis of Indole-Fused Heterocycles through Formal Cycloadditions of Indolyl-Allenes. J. Am. Chem. Soc. 2015, 137, 8131-8137. (d) Fang, R.; Feng, Z.; Kirillov, A. M.; Yang, L. Density Functional Theory Study of the Metal-Catalyzed Cycloaddition of Indolyl-Allenes: Possible Reaction Pathways, Stereoselectivity, and Regioselectivity. Organometallics 2020, 39, 1782-1789. For an intermolecular version of this transformation, see: (e) Jia, M.; Monari, M.; Yang, Q.-Q.; Bandini, M. Enantioselective Gold Catalyzed Dearomative [2+2]-Cycloaddition between Indoles and Allenamides. Chem. Commun. 2015, 51, 2320-2323. (f) Ocello, R.; De Nisi, A.; Jia, M.; Yang, Q.-Q.; Monari, M.; Giacinto, P.; Bottoni, A.; Miscione, G. P.; Bandini, M. Gold(I)-Catalyzed Dearomative [2+2]Cycloaddition of Indoles with Activated Allenes: A Combined Experimental-Computational Study. Chem. Eur. J. 2015, 21, 18445-18453. (g) Faustino, H.; Bernal, P.; Castedo, L.; López, F.; Mascareñas, J. L. Gold(I)-Catalyzed Intermolecular [2+2] Cycloadditions between Allenamides and Alkenes. Adv. Synth. Catal. 2012, 354, 1658-1664. Examples of Au-catalyzed synthesis of cyclobutane-fused carbocycles: (h) Jiménez-Núñez, E.; Claverie, C. K.; Nieto-Oberhuber, C.; Echavarren, A. M. Prins Cyclizations in Au-Catalyzed Reactions of Enynes. Angew. Chem. Int. Ed. 2006, 45, 5452-5455. (i) Sethofer, S. G.; Staben, S. T.; Hung, O. Y.; Toste, F. D. Au(I)-Catalyzed Ring 
Expanding Cycloisomerizations: Total Synthesis of Ventricosene. Org. Lett. 2008, 10, 4315-4318. (j) Zheng, H.; Felix, R. J.; Gagné, M. R. Gold-Catalyzed Enantioselective Ring-Expanding Cycloisomerization of Cyclopropylidene Bearing 1,5-Enynes. Org. Lett. 2014, 16, 2272-2275. (k) Chen, G. Q.; Fang, W.; Wei, Y.; Tang, X. Y.; Shi, M. Divergent Reaction Pathways in Gold-Catalyzed Cycloisomerization of 1,5-Enynes Containing a Cyclopropane Ring: Dramatic ortho Substituent and Temperature Effects. Chem. Sci. 2016, 7, 4318-4328.

(1) Zhang, J.; Wei, Y.; Shi, M. Gold-Catalyzed Ring Enlargement and Cycloisomerization of Alkynylamide tethered AlkylideneCyclopropanes. Org. Chem. Front. 2018, 5, 2980-2985.

(14) (a) Zi, W.; Toste, F. D. Recent Advances in Enantioselective Gold Catalysis. Chem. Soc. Rev. 2016, 45, 4567-4589. (b) Li, Y.; Li, W.; Zhang, J. Gold-Catalyzed Enantioselective Annulations. Chem. Eur. J. 2017, 23, 467-512.

(15) Deprotection of the nosyl group in compound $\mathbf{1 9 b}$ afforded the corresponding secondary amine $\mathbf{2 0 b}$ in $57 \%$ yield. See Supporting Information for more details. 


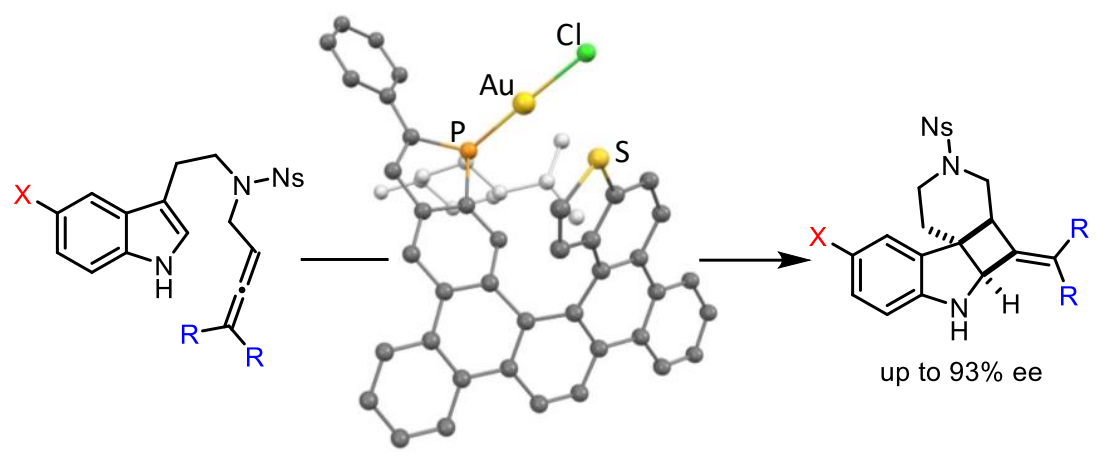

